http://www.pakjas.com.pk

\title{
EFFECTS OF PESTICIDES ON MALE FARMER'S HEALTH: A STUDY OF MUZAFFAR GARH
}

\author{
Muhammad Ali Tarar ${ }^{1, *}$, Muzaffar Hussain Salik², Madiha Riaz', Aqib Shahzad Alvi³, Amina \\ Hanif Tarar ${ }^{4}$, Kashif Mushtaq ${ }^{1}$, Saira Akhtar ${ }^{2}$ and Tanveer Sultan ${ }^{2}$ \\ ${ }^{1}$ Faculty of Management \& Social Sciences, Ghazi University, Dera Ghazi Khan, Punjab-Pakistan; ${ }^{2}$ University of \\ Agriculture, Faisalabad, Punjab-Pakistan; ${ }^{3}$ Department of Social work, University of Sargodha, Sargodha, Pakistan; \\ ${ }^{4}$ Department of Psychology, Govt. College University, Lahore-Pakistan. \\ "Corresponding author's e-mail: alitarar2000@yahoo.com
}

\begin{abstract}
Application of pesticides are made to control those insects and pest that approach the crops and damage them. From centuries, for the protection of crops, different sorts of pesticides are in practice. On the one hand pesticide benefits the crops, meanwhile it injurious for environment and \& human health. Because it's unnecessary application poses negative effects on biodiversity and all living organism i.e. birds, animals and human etc. faces threats for their survival. Study objectives were (i) to find out the effects of pesticides on farmer's health and (ii) to suggest some recommendations for future policy to improve farmer's health. For this study, a sample of 160 respondents (male farmers) were selected through multistage sampling technique. At first stage, 4 union councils from total $111 \mathrm{UCs}$, at second stage, 8 localities/ Basties /urban areas (2 from each union council) were selected randomly and at third stage, 20 respondents from each locality were selected by convenient sampling technique. Results showed that majority respondents were young illiterate married persons who were living in joint family system (62.5\%); had family income Rs. 12,001-25,000 (63.1\%); land tendency status of majority (91.3\%) was own cultivator and 1-4 acres cultivate per year $(45.0 \%)$. Majority $(86.9 \%)$ of the respondents said that through inhalation source pesticides enter the human body and they prepared the pesticides stuff in field (94.3\%). Data also showed about pesticides usage in crops and its different effects on farmer's health i.e. heard about illness caused by pesticides (87.5\%); is cause of air pollution (65.6\%); pesticides particularly harmful for farm workers health (88.8\%); after the application of pesticides, farmers faced health problems $(83.8 \%)$; family members felt sick $(71.9 \%)$ while after handling pesticides they faced shortness of breath $(75.6 \%)$; experienced redness of skin (69.4\%), nervous disorder (77.5\%), headache (56.9\%), excessive sweating (51.2\%), diarrhea (75.0\%); abdominal pain (73.1\%); eyes burning (85.0\%); respiratory disorder (76.3\%); dry cough (80.0\%); fever (81.2\%); dry throat (84.4\%); sleeplessness and laziness $(76.9 \%)$; vomiting $(78.8 \%)$; vision disturbance $(86.9 \%)$ and pesticides usage is the risk of cancer $(81.9 \%)$. Data showed that during pesticides spray respondents used the different personal protective equipment i.e. ordinary clothes to apply pesticides $(98.1 \%)$; long-sleeved shirt $(81.9 \%)$; spray coat with hoods $(80.0 \%)$; gumboots $(85.0 \%)$; nose masks $(89.4 \%)$; goggles $(66.2 \%)$ and hand gloves $(66.9 \%)$ as well as take a shower immediately after mixing/ spraying (86.9\%). Bi-variate analysis showed significant relationship between more the use of improper goggles vs. more the burning of eyes and more the use of improper nose mask vs. more the respiratory disorder problems among farmers. Govt. need to take strict action \& measures against producers of hazardous \& injurious pesticides and through intensive trainings, \& short term courses guide farmers regarding safe $\&$ harmless application of pesticides to protect themselves.

Keywords: Health problems, farm activities, pesticides, rural community, health knowledge, farm related health issues.
\end{abstract}

\section{INTRODUCTION}

Crop damage from pest infestations often results in serious consequences, warranting the need to use pesticides. However despite their benefits, pesticides pose potential hazards to human health and the environment when inappropriately handled (WHO, 1990; Kishi, 2005, Tarar et al., 2016). Agriculture is vital sector of Pakistani economy and pesticides are prominent tool that is widely practiced throughout the globe to control crop diseases; to promote agriculture production and quality as contemporary agricultural technology. From last few decades, pesticides application has been increased many times and approximately worldwide 5.2 billion pounds are applied each year not only in agriculture fields but also in homes to restricts different insects i.e. ants, mosquitoes, rat and flies etc. (Wilson and Tisdell, 2001; Damalas, 2009; Cooper and Dobson, 2007; Tarar et al., 2019; Mahmood et.al., 2016; Damalas and Eleftherohorinos, 2011).

Globally human population is rapidly increasing and demand for safe food and energy is inevitable to ignore because major share of food come from agriculture \& livestock activities. Farmers are key stakeholder of agricultural activities and their health, social welfare has key significance in achieving 
sustainable agricultural development and healthier food supply to society (Narahashi et al., 2007; Hosseini et al., 2008; Tarar et al., 2016; EPA, 2017). Pakistani farmers were usually unprotected to great height of pesticides, generally much larger than other users. It was frequently because of less awareness of farmers regarding amount of uses and means of application. Additionally, carelessness or lack of consultancy about pesticide application perhaps be another cause, that may put towards incidence of pesticide residues on farm products i.e. fruits, vegetables. Mostly farmers $(85.5 \%)$, to make the dose more effective $\&$ powerful, mixes many pesticides and reason behind it is that recommended rates are not operative because of rebirth of pests as well as to control the disease or diverse pests (Shafqat, 2017).

Pesticides are promptly becoming toxic for alive beings that are terminated in agro-industrial sector or even in water, soil and air which enhances stress and is a threat for healthy civilization. Fast population and industrial growth has posed serious concerns on our environment and health. Environmental and industrial contamination along with swift timber cutting/ deforestation as well as illegal and unplanned installation of factories are influencing human health by familiarizing toxic elements and physical material that are mostly remain in air, on soil or water surface polluting the earth planet, ending humanity and rising sea level, increasing normal earth temperature, drought, and frequency of floods. However, safeguarding nature and saving environment and expressing serious concerns on deforestation, smoke and industrial waste via public education can be supportive and govt. should pay strong emphasis to switch environmental degradation (Bourguet and Guillemaud, 2016; Fleming et al., 2003; Tarar et.al., 2019; Dawson et al., 2010; Damalas and Eleftherohorinos, 2011; Anwar, 2017; Ajmal et al., 2016; Tarar et al., 2017; Hassan et al., 2016; Mozart, 2018).

Unnecessary application of pesticides on fruit and vegetable crops are hazardous for health and environment that causing loss of billions rupees in our national economy beside domestic economy. Chemical insecticides are applied as the major source to control pest but over use of it causing pollution and becoming tricky for health of all living beings, especially human beings i.e. children, pregnant females, infant babies or farmers who visits farms or involve in farm activities, because chemical insecticides and pesticides remain present in crops, fruits and vegetables for many days after sprayed and more than 50\% marketed pesticides are unsafe and hazardous that can cause everything from a mild, vomiting, fatigue, headache to a skin allergy to cancer (breast, prostate etc.) as well as infertility, morbidity and mortality in developing countries (Reigart and Roberts, 2006; Bourguet and Guillemaud, 2016; Fleming et al., 2003; EPA, 2017; Tarar et.al., 2019; Dawson et al., 2010; Damalas and Eleftherohorinos, 2011; Wilson and Tisdell, 2001; Anonymous, 2018; Mughal, 2018; Tarar et al., 2016; Mozart, 2018).
Pakistan is spending approximately Rs.1001 billion in agriculture sector for timely availability of inputs i.e. fertilizer and pesticides etc. (Govt. of Pakistan, 2018) and more than Rs. 14 billion only on pesticides that are not only effecting human health but also causing increase annual death rate. So through awareness of farm community; use of diseaseresistance varieties in fields and strict monitoring of govt. agencies, unnecessary application of pesticides can be decreased in country. Because of low level of awareness, Farm workers are applying pesticides 10-15 times more than its requirement. Irrational and excessive practice of pesticides is also accountable for producing advanced hazards of cancer, tuberculosis among other humans; breathing disorder (Reigart and Roberts, 2006; Malik, 2011; WHO, 2011; Islam and Arif, 2011; Yousuf, 2012; Ajmal, et al., 2016, Tarar et al., 2016; EPA, 2017). More dependency on pesticides poses adverse penalties i.e. problems linked to protection of workers, ground water pollution, and adverse effects on farmer friendly insects and on beneficial arthropods including honey bees and others. So because of all these, food security obligatory to secure safe food for rapid growing population. In last 2 decades, application of pesticides in Pakistan has been increased many times. Its need of era that tendency of application must be reduced \& swapped by pest management because Pakistan ranked $5^{\text {th }}$ in production of mango and guava, $6^{\text {th }}$ in apricot and $7^{\text {th }}$ in dates production (Khan and Jaskani, 2013).

In Pakistan, generally, South Punjab, and its Muzaffar Garh District is very famous for production of different crops, like cotton, wheat, rice, sunflower, vegetables, mango and other crops. The agriculture department of Muzaffar Garh also works to enable and educate the farmers to earn more and improve living standards through adoption of precise, modern and environmental friendly production technologies of crops with suitable diversified patterns to reduce cost of production, minimize losses, increase yield, ensure maximum profit, and bring prosperity for farmers and strengthening the country. To save the crops many pesticides are used like thiophenatmethyal (fungicide for fungus in tomatoes and other vegetables and crops also), fipronil (insecticide for termites and other chewing insects of rice and sugarcane) etc. These pesticides are commonly used the crop yield, but it also impacts on farmer's health. Farmers reported multiple symptoms like headache, vomiting, respiratory problems, eye symptoms, muscle weakness and skin rash and many other clinical significant (Tarar et al., 2016; Ajmal et al., 2016). Because of low level of awareness, no use of protective measures (proper shoes, gloves, masks, gaggles, clothing etc.), careless attitude; unsatisfactory and improper equipment during application of pesticides, they are facing lungs problems, brain hemorrhage, disorder of immune system, cancer which are most likely because of acute pesticide effects. These pesticides also effects on animals, 
environmental conditions and water, which also effects on farmers and other human beings.

\section{MATERIAL AND METHODS}

Present study was designed in 2018 to investigate the effects of pesticides usage on farmer's health and health problems faced by male farm workers in rural areas of Muzafar Garh along with to study their knowledge \& attitude toward pesticide application and it effects. Multistage sampling procedure was used during selection of 160 respondents. According to district administration, there are 111 Union Councils in District Muzaffar Garh. At first stage, 4 union councils (UC \# 70 "Gul Qaim Mastoi”, UC \# 71 "Karam Dad Qureshi", UC\# 72 "Baseera", and UC \# 73 "Waan Pitafi") from total 111 union councils were chosen through simple random method, at second stage, 8 localities/ Basties /urban areas (2 from each union council) namely "UC \# 70 (i) Basti Daad; (ii) Basti Kamil; UC \# 71 (i) Karam Dad Qureshi City; (ii) Basti Peer Wala; UC \# 72 (i) Qalandar Wala; (ii) Baseera City; and UC \# 73 (i) Basti Kandh Wala; (ii) Basti Essan Wala, 2 were selected by simple random sampling technique and at third stage, 20 respondents from each locality were selected by convenient sampling technique. Univariate (frequencies \& percentage) and Bi-variate (Chi-square and Gamma) analysis was carried out.

\section{RESULTS AND DISCUSSION}

Human behavior can be determined through age because it points out the capacity to perform work and behavior of a person towards socio-economic aspect of life. Generally, age is measured by numbers of years completed by a person since his birth. To influence someone behavior, age is considered vital factor because it enlightens the one's exposure via experience. In Table 1 data shows that $40.6 \%$ of the respondents were of age 25-34 years, $28.1 \%$ of the respondents were of age $45 \&$ above years, $20.0 \%$ of the respondents were of age 35-44 years and $11.3 \%$ of the respondents were of age 18-24 years. In this table data also showed that majority (86.9\%) of the respondents were married and $13.1 \%$ of the respondents were unmarried.

Education can be defined as the process of developing knowledge, wisdom and other desirable qualities of mind, character and general competency, especially by the source of formal instruction. It is generally admitted that without education it is pretty difficult to produce good results in every sphere of life. In above table data shows that $25.6 \%$ of the respondents had illiterate (not educated), 20.6\% of the respondents had their educational level of matric, $15.6 \%$ of the respondents had their educational level of above graduation, $15.0 \%$ of the respondents had their educational level of middle, $11.9 \%$ of the respondents had their educational level of intermediate and $11.3 \%$ of the respondents had their educational level of primary. Similar results were found by Karim et al. (2016), they also perceived the negative effects of the growing harmful crops like tobacco. But it was reported that both illiterate and educated people grow tobacco for various reasons.

Data in Table 1 also showed that majority (62.5\%) of the respondents were living in joint family system, $31.9 \%$ of the respondents were living in nuclear family system and $5.6 \%$ of the respondents were living in extended family system. Family is primary institution of society and possess a key position in social structure. Generally, it is marked as assembly of persons tied by marriage, kinship or interacting role i.e. son, daughter $\&$ father, wife $\&$ husband or mother $\&$ father. It is assembled by common homage, reproduction or financial support and delivers its members different securities and supports. It varies society to society in its form, system, culture and living style. In Pakistan, people regard family as divinity and sacred and give good respect to cultural values of family. In urban areas, nuclear family system is in promotion while in rural areas still people are living in joint or extended family system (Mansoor, 2008). Table 1 shows that $40.6 \%$ of the respondents said that they had 4-7 family members, 39.4\% of the respondents said that they had 8-11 family members, $15.6 \%$ of the respondents said that they had $12 \&$ above family members and $4.4 \%$ of the respondents said that they have 1-4 family members.

Data regarding income in Table 1 shows that majority $(63.1 \%)$ of the respondents had their family income Rs. $12,001-25,000,18.1 \%$ of the respondents had their family income Rs. 25,001-40,000, equal response that $6.9 \%$ of the respondents their family income was Rs. Under 12,000 and $40,001-55,000,3.1 \%$ of the respondents had their family income was Rs. 55,001-70,000 and 1.9\% of the respondents had their family income was Rs. 70,001 and above.

Data regarding land tendency presented in Table 1 shows that majority $(91.3 \%)$ of the respondents were owner cultivator, $3.8 \%$ were owner-cum tenant, $3.1 \%$ were tenant, $1.2 \%$ were share cropper and $0.6 \%$ of the respondents said that their land tendency status was contractor. Only tenure relationships in privately held and cultivated land covering more than $90 \%$ of total cultivable land will be discussed. Acquisition and distribution of Khas land by the government and land ownership by various government and semi-government agencies will not be discussed mainly because these will involve a thorough review of the various land reform measure undertaken since 1950 and also because reliable data on these are not available at hand (Jabbar, 1978).

Table 1 shows that $45 \%$ of the respondents said that $1-4$ acres cultivate per year, $28.1 \%$ of the respondents said that less than 1 acre cultivate per year, $18.8 \%$ of the respondents said that 5-7 acres land cultivate per year, $6.2 \%$ of the respondents said that $12 \&$ above acres land cultivate per year and $1.9 \%$ of the respondents said that 8-11 acres land cultivate per year. 
Table 1. Frequency distribution of the respondents according to their socio-economic and demographic characteristics.

\begin{tabular}{|c|c|c|}
\hline Age of the respondents & Frequency & Percent \\
\hline $18-24$ & 18 & 11.3 \\
\hline $25-34$ & 65 & 40.6 \\
\hline $35-44$ & 32 & 20.0 \\
\hline $45 \&$ above & 45 & 28.1 \\
\hline Total & 160 & 100.0 \\
\hline \multicolumn{3}{|l|}{ Marital status } \\
\hline Unmarried & 21 & 13.1 \\
\hline Married & 139 & 86.9 \\
\hline Total & 160 & 100.0 \\
\hline \multicolumn{3}{|l|}{ Educational level } \\
\hline Illiterate & 41 & 25.6 \\
\hline Primary & 18 & 11.3 \\
\hline Middle & 24 & 15.0 \\
\hline Matric & 33 & 20.6 \\
\hline Intermediate & 19 & 11.9 \\
\hline Above graduation & 25 & 15.6 \\
\hline Total & 160 & 100.0 \\
\hline \multicolumn{3}{|l|}{ Family type } \\
\hline Nuclear & 51 & 31.9 \\
\hline Joint & 100 & 62.5 \\
\hline Extended & 9 & 5.6 \\
\hline Total & 160 & 100.0 \\
\hline \multicolumn{3}{|c|}{ Number of family members } \\
\hline $1-4$ & 7 & 4.4 \\
\hline $4-7$ & 65 & 40.6 \\
\hline $8-11$ & 63 & 39.4 \\
\hline $12 \&$ above & 25 & 15.6 \\
\hline Total & 160 & 100.0 \\
\hline \multicolumn{3}{|l|}{ Family monthly income } \\
\hline Under 12000 & 11 & 6.9 \\
\hline $12001-25000$ & 101 & 63.1 \\
\hline $25001-40000$ & 29 & 18.1 \\
\hline $40001-55000$ & 11 & 6.9 \\
\hline $55001-70000$ & 5 & 3.1 \\
\hline $70001 \&$ above & 3 & 1.9 \\
\hline Total & 160 & 100.0 \\
\hline \multicolumn{3}{|l|}{ Land tendency status } \\
\hline Owner cultivator & 146 & 91.3 \\
\hline Owner-cum tenant & 6 & 3.8 \\
\hline Tenant & 5 & 3.1 \\
\hline Contractor & 1 & 0.6 \\
\hline Share cropper & 2 & 1.2 \\
\hline Total ti & 160 & 100.0 \\
\hline \multicolumn{3}{|c|}{ Number of acres land they cultivate per year } \\
\hline Less than 1 acre & 45 & 28.1 \\
\hline $1-4$ acres & 72 & 45.0 \\
\hline 5-7 acres & 30 & 18.8 \\
\hline 8-11 acres & 3 & 1.9 \\
\hline $12 \&$ above acres & 10 & 6.2 \\
\hline Total & 160 & 100.0 \\
\hline \multicolumn{3}{|c|}{ Number of years they are involved in agricultural profession } \\
\hline $1-4$ & 29 & 18.1 \\
\hline $5-8$ & 56 & 35.0 \\
\hline $9 \&$ above & 75 & 46.9 \\
\hline Total & 160 & 100.0 \\
\hline
\end{tabular}

Data regarding involvement of respondents in agricultural profession shows in Table 1 that $46.9 \%$ of the respondents were involved in agricultural profession from 9 and above years, $35.0 \%$ were involved in agricultural profession from 58 years and $18.1 \%$ of the respondents said that from $1-4$ years, they are involved in agricultural profession.

In Table 2, data shows that majority $(78.8 \%)$ of the respondents said that they used the normal quantity of pesticide and $21.2 \%$ of the respondents said that they used frequent quantity of pesticide. Globally, almost 1.8 billion persons are involved in agriculture profession and uses pesticides to secure their productions for better incentives while others apply it professionally for public health programs or for their lawns \& in their homes to restrict insects and for safe livings (Alavanja, 2009). Data regarding application of pesticides in farms shows in Table-2 that majority (98.8\%) of the respondents were applying pesticides in their farm and $1.2 \%$ of the respondents said that farmers are not applying any pesticides in their farm. Mostly farmers apply pesticides to safe their crops from harmful insects and to enhance nutrients to the soil. Three sorts of pesticides are there i.e. a) herbicides, b) insecticides and c) fungicides. All these are applied to destroy different types of pests which are found in fields. Those agriculturists who don't apply chemicals on crops are referred as organic farmers.

Data regarding farmers' read and understanding instructions on the pesticide containers in Table 2 shows that majority (76.9\%) of the respondents said that they read and understand instructions on the pesticides containers and $23.1 \%$ of the respondents said that they did not read and understand instructions on the pesticides containers. According to NPIC (2018), labels of pesticides possess knowledge about its appropriate and legal application as well as also provide knowledge about its negative effects and methods how to avoid its potential hazards. If we follow the instructions and signs carefully we can minimize the losses and gain maximum incentives. Data regarding opinion about sign marks the most dangerous pesticides in Table 2 shows that majority (86.9\%) of the respondents said that skull and bones pictorials sign marks the most dangerous pesticides, $8.8 \%$ of the respondents said that red sign marks the most dangerous pesticides and $4.3 \%$ of the respondents said that don't know about sign marks the most dangerous pesticides. Maintain safety around herbicide and pesticide containers, as well as areas where they've recently been applied by installing these signs and labels that indicate the presence of hazardous poisons.

Data regarding opinion about they ever received any form of training to use and handle pesticide in Table 2 shows that majority $(59.4 \%)$ of the respondents said that they did not received any form of training to use and handle pesticides and $40.6 \%$ of the respondents said that they ever received any form of training to use and handle pesticides. 
Table 2. Frequency distribution of the respondents regarding their opinion about application of pesticides \& identify the reasons for the usage of pesticides in their crops.

\begin{tabular}{lcc}
\hline Use the quantity of pesticide & Frequency & Percent \\
\hline Frequently & 34 & 21.2 \\
Normal & 126 & 78.8 \\
Total & 160 & 100.0 \\
Farmers apply any pesticide in their farm & & \\
Yes & 158 & 98.8 \\
No & 2 & 1.2 \\
Total & 160 & 100.0 \\
They read and understand instructions on the pesticide containers \\
Yes & 123 & 76.9 \\
No & 37 & 23.1 \\
Total & 160 & 100.0 \\
Sign marks the most dangerous pesticides & & \\
Don't know & 7 & 4.3 \\
Red & 14 & 8.8 \\
Skull and bones pictorials & 139 & 86.9 \\
Total & 160 & 100.0 \\
They ever received any form of training to use and handle \\
pesticide & & \\
Yes & 65 & 40.6 \\
No & 95 & 59.4 \\
Total & 160 & 100.0 \\
Source of pesticides enter the human body & & \\
Dermal & 15 & 9.4 \\
Inhalation & 139 & 86.9 \\
Oral & 4 & 2.5 \\
Eye contact & 2 & 1.2 \\
Total & 160 & 100.0 \\
\hline
\end{tabular}

\begin{tabular}{llrr}
\hline $\begin{array}{l}\text { Identify the reasons for the usage of } \\
\text { pesticides in their crops }\end{array}$ & Frequency & Percent \\
\hline Use of pesticides help to & Always & 157 & 98.1 \\
the control crop related & Sometimes & 3 & 1.9 \\
disease & Never & 0 & 0.0 \\
& Total & 160 & 100.0 \\
Use of pesticides help to & Always & 152 & 95.0 \\
reduce crop losses & Sometimes & 8 & 5.0 \\
& Never & 0 & 0.0 \\
Pesticides protect crops & Total & 160 & 100.0 \\
from insect pests, weeds & Always & 128 & 80.0 \\
and fungal & Sometimes & 32 & 20.0 \\
& Never & 0 & 0.0 \\
They use pesticides & Total & 160 & 100.0 \\
commonly to increase the & Always & 152 & 95.0 \\
crop yield & Sometimes & 8 & 5.0 \\
& Never & 0 & 0.0 \\
Pesticides increased & Total & 160 & 100.0 \\
profits for farmers & Always & 144 & 90.0 \\
& Sometimes & 16 & 10.0 \\
& Never & 0 & 0.0 \\
Pesticide safeguard & Total & 160 & 100.0 \\
human health, by & Always & 129 & 80.6 \\
stopping food crops & Sometimes & 31 & 19.4 \\
& Never & 0 & 0.0 \\
\hline & Total & 160 & 100.0 \\
\hline
\end{tabular}

Identify the reasons for the usage of pesticides in their crops (Use of pesticides help to the control crop related disease): In above table data shows that majority $(98.1 \%)$ of the respondents said that always usage of pesticides in their crop was because of to the control crop related diseases, and 1.9\% of the respondents said that sometimes usage of pesticides in their crop was because of to the control crop related diseases. Condition of agriculture is to be safe, healthy and sustainable, it is essential to have healthy crops; they play a role in producing sufficient quantities of healthy foods and contribute to the quality of life. Our research into disease and pest management for the agricultural and horticultural sectors focuses on the interaction between crops and the diseases and pests that affect them. We use our knowledge of this subject to enable successful and sustainable integrated crop protection to be applied in practice (Jan, 2018; Yusuf, 2012; WHO, 2011; Tarar et al., 2016; Shafqat, 2017; Reigart and Roberts, 2006; Malik, 2011).

Reasons for the usage of pesticides in their crops (use of pesticides help reduce crop losses) to reduce crop losses): In Table 2 data shows that majority $(95.0 \%)$ of the respondents said that always usage of pesticides in their crops to reduce crops losses and 5.0\% of the respondents said that sometimes used of pesticides in their crops to reduce crops losses. Presently, food security and its durable sustainable development is most prominent world target because of rapid increase in global population. Earth planet resources are under high pressure due to increasing urbanization, changing of living and diet patterns of developing economies, diminishing of safe water \& biodiversity and climate change etc. So, there required collective and contemporary global methods to ensure safe \& sustainable food production \& utilization (Jan, 2018; Yusuf, 2012; WHO, 2011; Shafqat, 2017; Reigart and Roberts, 2006; Malik, 2011).

Pesticides usage in crops and its effects on farmer's health (They have experienced any health problems after the application of pesticides): In Table 3 data shows that majority $(83.8 \%)$ of the respondents said that they have often experienced any health problems after the application of pesticides, $15.6 \%$ of the respondents said that sometimes they have experienced any health problems after the application of pesticides and $0.6 \%$ of the respondents said that they had never experienced any health problems after the application of pesticides.

Pesticides usage in crops and its effects on farmer's health (They have ever experience eyes burning): In above table, data shows that majority $(85.0 \%)$ of the respondents said that they have often ever experience eyes burning, $14.4 \%$ of the respondents said that sometimes they have ever experience eyes burning and $0.6 \%$ of the respondents said that they had not often ever experience eyes burning. 
Table 3. Frequency distribution of the respondents regarding their opinion about pesticides usage in crops and its effects on farmer's health.

\begin{tabular}{|c|c|c|c|}
\hline $\begin{array}{l}\text { Opinion about pesticides us } \\
\text { and its effects on farmer's } h\end{array}$ & $\begin{array}{l}\text { age in crops } \\
\text { ealth }\end{array}$ & Frequency & Percent \\
\hline The widespread use of & Often & 105 & 65.6 \\
\hline pesticides is a caused by air & Sometimes & 55 & 34.4 \\
\hline pollution & Never & 0 & 0.0 \\
\hline & Total & 160 & 100.0 \\
\hline The widespread use of & Often & 95 & 59.4 \\
\hline pesticides is a significant & Sometimes & 65 & 40.6 \\
\hline source of soil pollution & Never & 0 & 0.0 \\
\hline & Total & 160 & 100.0 \\
\hline Pesticide use have harmful & Often & 144 & 90.0 \\
\hline effects on human health & Sometimes & 16 & 10.0 \\
\hline & Never & 0 & 0.0 \\
\hline & Total & 160 & 100.0 \\
\hline Pesticides are particularly & Often & 142 & 88.8 \\
\hline harmful for farm workers & Sometimes & 18 & 11.2 \\
\hline health & Never & 0 & 0.0 \\
\hline & Total & 160 & 100.0 \\
\hline Pesticides are hazardous for & Often & 25 & 15.6 \\
\hline female farmers & Sometimes & 134 & 83.8 \\
\hline & Never & 1 & 0.6 \\
\hline & Total & 160 & 100.0 \\
\hline Fruit and vegetable crops is & Often & 32 & 20.0 \\
\hline a negative health effects on & Sometimes & 128 & 80.0 \\
\hline farmer's health & Never & 0 & 0.0 \\
\hline & Total & 160 & 100.0 \\
\hline Any health problem after the & Often & 134 & 83.8 \\
\hline application of pesticides & Sometimes & 25 & 15.6 \\
\hline & Never & 1 & 0.6 \\
\hline & Total & 160 & 100.0 \\
\hline They take a shower & Often & 139 & 86.9 \\
\hline immediately after mixing or & Sometimes & 21 & 13.1 \\
\hline spraying pesticides & Never & 0 & 0.0 \\
\hline & Total & 160 & 100.0 \\
\hline Their family members felt & Often & 115 & 71.9 \\
\hline sick because of pesticide use & Sometimes & 44 & 27.5 \\
\hline & Never & 1 & 0.6 \\
\hline & Total & 160 & 100.0 \\
\hline They experienced shortness & Often & 121 & 75.6 \\
\hline of breath after handling & Sometimes & 39 & 24.4 \\
\hline pesticides & Never & 0 & 0.0 \\
\hline & Total & 160 & 100.0 \\
\hline They have ever experience & Often & 111 & 69.4 \\
\hline redness of skin them started & Sometimes & 49 & 30.6 \\
\hline pesticides & Never & 0 & 0.0 \\
\hline & Total & 160 & 100.0 \\
\hline They have ever experience & Often & 34 & 21.3 \\
\hline nervous disorder & Sometimes & 124 & 77.5 \\
\hline & Never & 2 & 1.2 \\
\hline & Total & 160 & 100.0 \\
\hline They have suffered from the & Often & 91 & 56.9 \\
\hline headache using pesticides & Sometimes & 69 & 43.1 \\
\hline & Never & 0 & 0.0 \\
\hline & Total & 160 & 100.0 \\
\hline They have ever experience & Often & 82 & 51.2 \\
\hline excessive sweating & Sometimes & 78 & 48.8 \\
\hline & Never & 0 & 0.0 \\
\hline
\end{tabular}

\begin{tabular}{|c|c|c|c|}
\hline \multicolumn{2}{|c|}{$\begin{array}{l}\text { Opinion about pesticides usage in crops } \\
\text { and its effects on farmer's health }\end{array}$} & \multirow{2}{*}{$\begin{array}{c}\text { Frequency } \\
160\end{array}$} & \multirow{2}{*}{$\begin{array}{l}\text { Percent } \\
100.0\end{array}$} \\
\hline \multirow{4}{*}{$\begin{array}{l}\text { They have ever experience } \\
\text { diarrhea }\end{array}$} & Total & & \\
\hline & Often & 39 & 24.4 \\
\hline & Sometimes & 120 & 75.0 \\
\hline & Never & 1 & 0.6 \\
\hline \multirow{4}{*}{$\begin{array}{l}\text { They have ever experience } \\
\text { abdominal pain }\end{array}$} & Total & 160 & 100.0 \\
\hline & Often & 42 & 26.3 \\
\hline & Sometimes & 117 & 73.1 \\
\hline & Never & 1 & 0.6 \\
\hline \multirow{4}{*}{$\begin{array}{l}\text { They have ever experience } \\
\text { eyes burning }\end{array}$} & Total & 160 & 100.0 \\
\hline & Often & 136 & 85.0 \\
\hline & Sometimes & 23 & 14.4 \\
\hline & Never & 1 & 0.6 \\
\hline \multirow{4}{*}{$\begin{array}{l}\text { They have ever experience } \\
\text { respiratory disorder }\end{array}$} & Total & 160 & 100.0 \\
\hline & Often & 122 & 76.3 \\
\hline & Sometimes & 36 & 22.5 \\
\hline & Never & 2 & 1.2 \\
\hline \multirow{4}{*}{$\begin{array}{l}\text { They have ever experience } \\
\text { dry cough }\end{array}$} & Total & 160 & 100.0 \\
\hline & Often & 128 & 80.0 \\
\hline & Sometimes & 31 & 19.4 \\
\hline & Never & 1 & 0.6 \\
\hline \multirow{4}{*}{$\begin{array}{l}\text { They have ever experience } \\
\text { fever }\end{array}$} & Total & 160 & 100.0 \\
\hline & Often & 130 & 81.2 \\
\hline & Sometimes & 30 & 18.8 \\
\hline & Never & 0 & 0.0 \\
\hline \multirow{4}{*}{$\begin{array}{l}\text { They have ever experience } \\
\text { dry throat }\end{array}$} & Total & 160 & 100.0 \\
\hline & Often & 135 & 84.4 \\
\hline & Sometimes & 25 & 15.6 \\
\hline & Never & 0 & 0.0 \\
\hline \multirow{5}{*}{$\begin{array}{l}\text { They have ever experience } \\
\text { sleeplessness and laziness }\end{array}$} & Total & 160 & 100.0 \\
\hline & Often & 123 & 76.9 \\
\hline & Sometimes & 37 & 23.1 \\
\hline & Never & 0 & 0.0 \\
\hline & Total & 160 & 100.0 \\
\hline \multirow{3}{*}{$\begin{array}{l}\text { They have ever experience } \\
\text { vomiting }\end{array}$} & Often & 34 & 21.2 \\
\hline & Sometimes & 126 & 78.8 \\
\hline & Never & 0 & 0.0 \\
\hline \multirow{4}{*}{$\begin{array}{l}\text { They have ever experience } \\
\text { vision disturbance }\end{array}$} & Total & 160 & 100.0 \\
\hline & Often & 21 & 13.1 \\
\hline & Sometimes & 139 & 86.9 \\
\hline & Never & 0 & 0.0 \\
\hline \multirow{5}{*}{$\begin{array}{l}\text { Use of pesticides caused by } \\
\text { health problems, the risk of } \\
\text { cancer }\end{array}$} & Total & 160 & 100.0 \\
\hline & Often & 20 & 12.5 \\
\hline & Sometimes & 131 & 81.9 \\
\hline & Never & 9 & 5.6 \\
\hline & Total & 160 & 100.0 \\
\hline \multirow{4}{*}{$\begin{array}{l}\text { Pesticide chemical poisoning } \\
\text { issues to the community } \\
\text { elders }\end{array}$} & Often & 38 & 23.8 \\
\hline & Sometimes & 122 & 76.2 \\
\hline & Never & 0 & 0.0 \\
\hline & Total & 160 & 100.0 \\
\hline \multirow{3}{*}{$\begin{array}{l}\text { Safe storage and disposal of } \\
\text { pesticides and fertilizers }\end{array}$} & Often & 127 & 79.4 \\
\hline & Sometimes & 33 & 20.6 \\
\hline & Never & 0 & 0.0 \\
\hline \multirow{5}{*}{$\begin{array}{l}\text { Local government having a } \\
\text { strict supervision overuse }\end{array}$} & Total & 160 & 100.0 \\
\hline & Often & 153 & 95.6 \\
\hline & Sometimes & 7 & 4.4 \\
\hline & Never & 0 & 0.0 \\
\hline & Total & 160 & 100.0 \\
\hline
\end{tabular}


Burning eyes can have several possible causes, ranging from the simple to the complex, and the burning sensation can occur with or without other symptoms such as itching, eye pain, watery eyes or discharge. According to Hellem and Heiting (2016) and Tarar et al. (2016), due to inevitable environmental effects i.e. wind, dust storms and pollen count, or because of pesticides, regular spectacle issues are occurring i.e., hot-red eyes or burning \& itching in eyes. However sometime more serious spectacle issues appear that required appropriate and intensive medical treatments and before treatment it's most important that identify the cause of that spectacle issue or problem.

Pesticides usage in crops and its effects on farmer's health (They have ever experience respiratory disorder): In Table 3 data shows that majority $(76.3 \%)$ of the respondents said that they have often ever experience respiratory disorder, $22.5 \%$ of the respondents said that sometimes they have ever experience respiratory disorder and $1.2 \%$ of the respondents said that they had not ever experience respiratory disorder. According to Sengupta et al. (2016), and Tarar et al., (2016) in medical terminology, breathing infections are known as respiratory diseases which is comprised of pathological settings which affects the parts \& tissues that make possible gas exchange in advanced organisms and comprised of upper breathing tract, bronchi, pleura and bronchioles etc. and respiratory nerves $\&$ muscles. These breathing diseases can be from mild common cold to life-threatening bodies/ conditions i.e. bacterial pneumonia, chronic asthma and cancer of lungs.

Usage in crops and its effects on farmer's health (They have ever experience dry cough): In above table data shows that majority $(80.0 \%)$ of the respondents said that they have often ever experience dry cough, $19.4 \%$ of the respondents said that sometimes they have ever experience dry cough and $0.6 \%$ of the respondents said that they had not ever experience dry cough. In dry cough type no phlegm or mucus is formed (Identified as non-productive). It is grating and commonly attached by itching throat. It is mostly associated with viral sickness as flu or cold but these can be because of allergies or irritants of throat (Judy et al., 1991).

Pesticides usage in crops and its effects on farmer's health (Suggest that local government having a strict supervision overuse of pesticide): In Table 3, data shows that majority $(95.6 \%)$ of the respondents said that often suggested that local government having a strict supervision overuse of pesticide and $4.4 \%$ of the respondents said that sometimes suggest that local government having a strict supervision overuse of pesticide.

During pesticide spray use any personal protective equipment (They wear an improper nose masks during the time of pesticides): In Table 4, data shows that majority $(89.4 \%)$ of the respondents said that they wear often improper nose masks during the time of pesticides and $10.6 \%$ of the respondents said that sometimes they wear improper nose masks during the time of pesticides. According to Tarar et al. (2016) and, Damalas and Eleftherohorinos (2011) people inhales much quantity of pesticides by the respiratory system (Nose and lung). So, people wear special kits/ devices that are designed with particle cartilages or canister on certain events/ conditions when they are working with pesticides or walk through certain environment to avoid dust particles, smoke or pesticide vapors and fumes because disposable or ordinary masks cannot provide sufficient safety and protection especially during pesticide application.

Table 4. Frequency distribution of the respondents regarding their opinion about during pesticide spray use any personal protective equipment.

\begin{tabular}{llrr}
\hline $\begin{array}{l}\text { During pesticide spray use any } \\
\text { personal protective equipment }\end{array}$ & Frequency & Percent \\
\hline They wear ordinary clothes & Often & 157 & 98.1 \\
to apply pesticides & Sometimes & 3 & 1.9 \\
& Never & 0 & 0.0 \\
& Total & 160 & 100.0 \\
They wear long-sleeved & Often & 131 & 81.9 \\
shirt to apply pesticides & Sometimes & 29 & 18.1 \\
& Never & 0 & 0.0 \\
They used spray coat with & Total & 160 & 100.0 \\
hoods & Often & 31 & 19.4 \\
& Sometimes & 128 & 80.0 \\
They wear a gumboots & Total & 1 & 0.6 \\
during the time of & Often & 160 & 100.0 \\
pesticides & Sometimes & 24 & 15.0 \\
& Never & 136 & 85.0 \\
They wear an improper & Total & 0 & 0.0 \\
nose masks during the time & Often & 160 & 100.0 \\
of pesticides & Sometimes & 143 & 89.4 \\
They used improper & Never & 0 & 10.6 \\
goggles during the time of & Total & 160 & 0.0 \\
pesticides & Often & 106 & 66.2 \\
\multirow{2}{*}{$\begin{array}{l}\text { They used hand gloves to } \\
\text { apply pesticides }\end{array}$} & Never & 54 & 33.8 \\
& Total & 0 & 0.0 \\
& Often & 160 & 100.0 \\
& Nometimes & 107 & 66.9 \\
& Total & 53 & 33.1 \\
& 0.0 & 0.0 \\
& & 160 & 100.0 \\
\hline
\end{tabular}

During pesticide spray use any personal protective equipment (They used improper goggles during the time of pesticides): In Table 4 data shows that majority (66.2\%) of the respondents said that they often used improper goggles during the time of pesticides and $33.8 \%$ of the respondents said that sometimes they used improper goggles during the time of pesticides. Judy et al. (1991) and Tarar et al. (21016) reported similar findings and they said if someone looking for safety kits or protective tools as safety equipment they should found these in telephonic directory's yellow pages or in 
modern era internet has made it more easy and convenient. For farmers and related communities such protective equipment i.e. boots, gloves, goggles, face shields, hats, rain suits etc. should be available at agriculture, veterinary, rescue and safety and building departments on subsides rates or affordable rent.

During pesticide spray use any personal protective equipment (They used hand gloves to apply pesticides): In above table data shows that majority $(66.9 \%)$ of the respondents said that they often used hand gloves during the time of pesticides and $33.1 \%$ of the respondents said that sometimes they used hand gloves during the time of pesticides. During application or utilization of pesticides or handling pesticide containers, tools, clothes, material or equipment, one should protect his hand and eyes. 12 inches long, unlined gloves are more effective during handling of undiluted or high toxic pesticides. Avoid scratched, cotton or leather gloves because it absorbs sufficient quantity of pesticides and hard to clean thoroughly and apply nitrite, butyl rubber or neoprene gloves. To avoid hazardous effect of pesticides, always handle it carefully and wear safety equipment (Judy et al., 1991; Tarar et al., 2016).

Hypothesis - 1: More will be the use of improper goggles during the time of pesticides; more will be the burning of eyes

Table 5. Association between farmers' used improper goggles during the time of pesticide and they have experience eyes burning.

\begin{tabular}{|c|c|c|c|c|}
\hline \multirow{2}{*}{$\begin{array}{l}\text { Farmers' used } \\
\text { improper goggles } \\
\text { during the time of } \\
\text { pesticide }\end{array}$} & \multicolumn{3}{|c|}{$\begin{array}{c}\text { They have experience eyes } \\
\text { burning; } \mathrm{X}^{2}=31.176,(\mathrm{p}=.000) ; \gamma \\
=.875,(\mathrm{p}=.000)\end{array}$} & \multirow[t]{2}{*}{ Total } \\
\hline & Often & Sometimes & Never & \\
\hline Often & 102 & 4 & 0 & 106 \\
\hline Sometimes & 34 & 19 & 1 & 54 \\
\hline Total & 136 & 23 & 1 & 160 \\
\hline
\end{tabular}

Pearson chi-square (31.176) value in Table-5 explores a statistically significant (probability $=0.000$ ) association between the variables. The Gamma value $(0.875)$ shows a positive correlation between the variables. This relationship between farmers' used goggles during the time of pesticide and they have experience eyes burning but significant $(P$ $=0.000$ ). Keeping in mind obtained hypothesis quantitative figures the researcher can say that farmers' used improper goggles during the time of pesticide and they have experience eyes burning. Consequently, keeping in mind theses obtained results present hypotheses titled "less the use of goggles during the time of pesticides; more the burning of eyes" is statically accepted.

Hypothesis - 2: More will be the use of improper nose mask during the time of pesticides; more will be the respiratory disorder problems among farmers
Table 6. Association between farmers' wear an improper nose masks during the time of pesticides and experienced respiratory disorder.

\begin{tabular}{lcccr}
\hline Farmers wear an & & \multicolumn{2}{c}{$\begin{array}{c}\text { They experienced respiratory } \\
\text { improper nose masks } \\
\text { during the time of }\end{array}$} & \multicolumn{2}{c}{ Total } \\
pesticides & $\mathbf{. 0 0 6}) ; \boldsymbol{\gamma}=\mathbf{. 6 0 8},(\mathbf{p}=\mathbf{. 0 2 3})$ & \\
\cline { 2 - 4 } & $\mathbf{O f t e n}$ & Sometimes & Never & \\
\hline Often & 114 & 27 & 2 & 143 \\
Sometimes & 8 & 9 & 0 & 17 \\
Total & 122 & 36 & 2 & 160 \\
\hline
\end{tabular}

Pearson chi-square (10.197) value in Table 6 explores a statistically significant (probability $=0.006$ ) association between the variables. The Gamma value (0.608) shows a positive correlation between the variables. This relationship between farmers wears a nose masks during the time of pesticides and having experienced respiratory disorder but significant $(\mathrm{P}=0.006)$. Keeping in mind obtained hypothesis quantitative figures the researcher can say that farmers wore an improper nose masks during the time of pesticides and had experienced respiratory disorder. Consequently, keeping in mind theses obtained results present hypotheses titled "More the use of improper nose mask during the time of pesticides; more the respiratory disorder problems among farmers" is statically accepted.

Conclusion: In Pakistan, generally, South Punjab, and its Muzaffar Garh District is very famous for production of different crops, like cotton, wheat, rice, sunflower, vegetables, mango, oil seed and other crops. The farmers used many types of pesticides to protect their crops from pests and also used to increase their profit and production of crops. By using these pesticides, farm workers have faced different kinds of side-effects on their bodies i.e. skin redness, breath shortness, dry cough, disorder in nervous system and acute fever etc. In this regard, govt. need to take strict action \& measures against producers of hazardous \& injurious pesticides, through intensive trainings, short term courses and guide farmers regarding safe \& harmless application of pesticides to protect themselves and other farmworkers from negative effects and to make their health more safer and better new rural health policy should be implemented in which regular medical checkups of farmworkers should be made compulsory through mobile health units and rural health centers. There is also need to stimulate technical, systematic \& community based initiatives to make development \& practice of substitutes to pesticides more cheap, viable in a wide variety of managed and natural ecosystems.

\section{REFERENCES}

Ajmal, M., M.A. Tarar, M.I. Arshad, A.B. Gulshan, M.A. Iqbal and F. Tanvir. 2016. Air Pollution and Its Effect on 
Human Health: A Case Study in Dera Ghazi Khan Urban Areas, Pakistan. J. Environ. Earth Sci.; 6:87-93.

Anonymous. 2018. Excessive use of pesticide hazardous. Express Tribune, $18^{\text {th }}$ May 2018. Available online at https://tribune.com.pk/story/1712832/1-excessive-usepesticides-hazardous/

Anwar, M. 2017. Pesticide fast becoming a pest for the environment. Express Tribune, 24 July 2017. Available online at https://tribune.com.pk/story/1464996/pesticidefast-becoming-pest-environment/

Bourguet, D. and T. Guillemaud. 2016. The hidden and external costs of pesticide use. Sust. Agric. Rev. 1:35120.

Cooper, J. and H. Dobson. 2007. The benefits of pesticides to mankind and the environment. Crop Prot. 26:1337-1348

Damalas, C.A. 2009. Understanding benefits and risk of pesticide use. Sci. Res. Essays 4:945-949.

Damalas, C.A and I.G. Eleftherohorinos. 2011. Pesticide exposure, safety issues and risk assessment indicators. Int. J. Environ. Rese. Public Health 8:1402-1419.

Dawson, A.H., M. Eddleston, L. Senarathna, F. Mohamed and I. Gawarammana. 2010. Acute human lethal toxicity of agricultural pesticides: A prospective cohort study. Available online at https://journals.plos.org/plosmedicine/article?id=10.137 1/journal.pmed.1000357

EPA. 2017. Human health issues related to pesticides. Environmental Protection Agency (EPA). Available online at https://www.epa.gov/pesticide-science-andassessing-pesticide-risks/human-health-issues-relatedpesticides

Fleming, L.E., O.G. Marin, D. Zheng, F. Ma and D. Lee. 2003. National health interview survey mortality among US farmers and pesticide applicators. Am. J. Ind. Med. 43:227-233.

Govt. of Pakistan. 2018. Growth and Investment: Pakistan Economic Survey 2017-18. Economic Adviser's Wing, Finance Division, Government of Pakistan, Islamabad, Pakistan.

Hassan, M.A., M.A. Tarar, M.I. Arshad, A.B. Gulshan and M.A. Iqbal. 2016. Determinants and consequences of deforestation in the Indus River belt area of Dear Ghazi Khan, Pakistan. J. Environ. Earth Sci. 6:35-43.

Hosseini, M., A. Ramazani, H. Tavasolian, M. Mohsenzadeh, S. Maleki and K. Samimi. 2008. Survey of knowledge and attitude of farmers of Southern Khorasan province regarding agriculture related OHS issues in 2008. Iran Occupational Health 8:24-29.

Islam, S. and M.J. Arif. 2011. Heavy use of pesticide causes many deaths. Express Tribune, October 2, 2011. Available online at https://tribune.com.pk/story/264833/heavy-use-ofpesticide-causes-many-deaths/
Jan, W. 2018. Diseases and pests in crops. Available online at https://www.wur.nl/en/Research-Results/ResearchInstitutes/plant-research/Biointeractions-PlantHealth/Diseases-and-pests-in-crops.htm

Khan, I.A. and J. Jaskani. 2013. Pest management: Pesticides should be used as a last resort. Express Tribune, December 1, 2013. Available online at https://tribune.com.pk/story/639398/pest-managementpesticides-should-be-used-as-a-last-resort/

Kishi, M. 2002. Farmers' perceptions of pesticides, and resultant health problems from exposures. Int. J. Occup. Environ. Health 8:175-181.

Mahmood, I., S.R. Imadi, K. Shazadi, A. Gul and K.R. Hakeem. 2016. Effects of pesticides on environment. Plant Soil Microbes 3:253-367

Malik, S. 2011. Health hazard: Life saving pesticides trigger rash of allergies. Express Tribune, October 7, 2011. Available online at https://tribune.com.pk/story/268587/health-hazard-lifesaving-pesticides-trigger-rash-of-allergies/

Mozart, M. 2018. Pesticides are used all around us, in homes and gardens, schools, parks and agricultural fields. An article published in Pesticide Action Network: North America on 2018. Available online at http://www.panna.org/pesticides-big-picture/pesticides101

Mughal, F.H. 2018. Environmental impact of pesticide overuse. Available online at https://www.dawn.com/news/1406013

Narahashi, T., X. Zhao, T. Ikeda, K. Nagata and J.Z. Yeh. 2007. Review differential actions of insecticides on target sites: basis for selective toxicity. Human Experience Toxicology 26:361-366.

Reigart, J.R. and J.R. Roberts. 2006. Potential health effects of pesticides. Available online at https://extension.psu.edu/potential-health-effects-ofpesticides

Shafqat, M. 2017. Study reveals use of toxic pesticides across Punjab. Express Tribune, 29 November 2017. Available online at https://tribune.com.pk/story/1570979/1-studyreveals-use-toxic-pesticides-across-punjab/

Tarar, M.A., T. Fatima, M.H. Salik, S. Akhtar, Y.N. Khan, T. Sultan, F. Ahmad, I.A. Warraich and S. Yasmin. 2016. Health problems faced by female farm workers in rural areas of tehsil Dera Ghazi Khan: A sociological investigation. J. Dow Uni. Health Sci. 10:35-38.

Tarar, M.A., M.I. Arshad, N. Akhtar, N. Akhter, M.B. Akram, A. Munir, S. Akhtar, Z. Batool, S. Siddique, Y.N. Khan, N.K. Mahsud, M.H. Salik, M. Ali and M.A. Iqbal. 2017. A sociological study about the need of agricultural extension services for rural women in Tehsil Dera Ghazi Khan-Pakistan. Transylvanian Rev. 25:4728-4736.

Tarar, M.A., Y.N. Khan, M.Z. Ullah, M.H. Salik, S. Akhtar and T. Sultan. 2019. Knowledge and attitude; Pregnancy 
and antenatal care among young agrarian \& non-agrarian females in Faisalabad District, Pakistan. Pak. J. Agri. Sci. 56:261-273.

WHO. 1990. Public health impact of pesticides used in agriculture. World Health Organization, Geneva, Switzerland.

WHO. 2011. Impact of pesticides on crops. World Health Organization (WHO). Available online at https://www.dawn.com/news/64306
Wilson, C and C. Tisdell. 2001. Why farmers continue to use pesticides despite environmental, health and sustainability costs. Ecological Econ. 39:449-462.

Yusuf, S. 2012. Pakistani crop-pickers exposed to hazardous pesticides, study reveals. Express Tribune, $31^{\text {st }}$ August 2012. Available online

at 